Małgorzata Buśko*

\title{
Analysis of Changes in Drafting a Base Map in View of Amendments to the Provisions of Law**
}

\section{Introduction}

Since 1979, the records of the base map in Poland were regulated by the provisions contained in the subsequent editions of the Technical Guideline K-1 [8]. They were universally applicable technical standards, referred to in the Regulation of the Minister of Internal Affairs and Administration of 24 March 1999 [16], with the Appendix containing a list of technical standards.

The list included the subsequent versions of the Technical Guideline K-1, in the following order:

- Technical Guideline K-1 “The Base Map", implemented by the Decree of the President of the Head Office of Land Surveying and Cartography of 9 February 1979, amended by the Decree No. 1 of the President of the Head Office of Land Surveying and Cartography of 24 February 1984 (Official Journal of the Head Office of Land Surveying and Cartography No. 1, item 1),

- Technical Guideline K-1 "The Base Map of the Country", implemented by the Surveyor General of Poland by the letter of 16 May 1995,

- Technical Guideline K-1 “The Base Map", issued in 1998 by the Surveyor General of Poland.

As the above list demonstrates, four dates of changes to the provisions of the Technical Guideline K-1 are important: 1979, 1984, 1995 and 1998. A significant part of the Guideline was occupied by the description of the principles of mapping the individual elements of the base map, which was drawn up on the matrices in the analog form, using drawing tools [12]. Only the last edition of the Guideline of 1998 allowed for the base map to be drawn up both in the analog form as well as with the information systems, which are used to establish and run land information system.

\footnotetext{
* AGH University of Science and Technology Faculty of Mining Surveying and Environmental Engineering, Department of Integrated Geodesy and Cartography, Krakow, Poland

** Statutory Research no. 11.11.150.444
} 
The Guideline K-1, as well as other technical guidelines, was voided by the provision of Article 35 of the Act of 4 March 2010 on the Infrastructure for Spatial Information [19]. As a consequence of this Act entering into force, a number of regulations concerning surveying works and surveying documentation were issued in Poland. The most important in this respect is the BDOT Regulation of 2013 [14]. However, due to the entry into force of the Act of 5 June 2014 amending the Act - Geodetic and Cartographic Law and the Law on enforcement proceedings in administration [20], the status of this Regulation was changed to "considered abrogated". Due to the enormity of the content, it was split into two regulations, which came into force in 2015 - one for the district and national databases of surveying records of public utilities and another one - on the databases of topographic objects and the base map (the BDOT Regulation, 2015) [15].

The current wording of Article 2 clause 7 of the Geodetic and Cartographic Law, after the above-mentioned amendment in 2014, the definition of the base map was re-formulated. Its current definition is as follows:

[...] the base map - understood as the large-scale cartographic document, containing information about the spatial location of: geodetic control points, record parcels, buildings, contours of land use, classification contours, networks of public utilities, building structures and technical infrastructure, and other topographic objects, as well as selected descriptive information about these objects.

The Geodetic and Cartographic Law amended in 2014 also applies to the planned date of a complete implementation of the digital base map by the of geodetic and cartographic documentation centers in Poland, by adding the wording of Article 53b section 2:

In the period from 1 January 2014 to 31 December 2016, in the case of a failure to create databases, [...], the base map can be kept in the vector form, as applied prior to 1 January 2014, or in the raster form, systematically supplemented with vector data.

This provision legally sanctioned the situation existing in some geodetic and cartographic documentation centers, where the base map was kept in the raster form, which was only the electronically processed analogue map. There is a high probability of an emerging necessity of further extension of the deadline of 31 December 2016 as the ultimate date in terms of the admissibility of the existence of raster maps, and even analogue maps in Poland.

Due to the rapidly changing legal status in Poland regarding the base map, it happens that the base map is sometimes kept in various forms, according to different technical standards. Such diversity frequently applies even to neighboring districts, or even cadastral districts. Therefore, it is justified to conduct a comparative analysis of the presentation of selected elements of the content of the base map, kept according to different standards, which is the primary objective of this study. 


\section{Comparison of the General Assumptions of Keeping the Base Map According to the Technical Guideline K-1, and Pursuant to the BDOT Regulations}

The Technical Guideline K-1 of 1998 consisted of three parts and three Appendixes. The instructions contained in the first part defined the four basic scales in which the base map could be prepared: 1:500, 1:1000, 1:2000 and 1:5000. The scale was selected depending on the degree of concentration of the details making up the content of the map, and the projected investment plans. The first part of the Guideline also specified the elements belonging to the obligatory content of the base map. These included: control points, elements of the cadastre and elements of the network of public utilities.

The second part of the Technical Guideline K-1 included instructions for the keeping of the base map, which was intended to be eventually converted to the vector form, associated with the database on the objects. The unambiguity of this information was guaranteed by unique digital or alphabetic code for identifying the details and assigning graphic characters to them. In addition, each object representing the content of the digital map had to be assigned spatial attributes, specifying its location, and descriptive attributes, specifying other properties of the object, e.g. description texts. The requirement of Guideline K-1 was that only those elements which were measured with sufficient accuracy, resulting from separate technical instructions, could be introduced to the map.

The last part of the Technical Guideline K-1 set out the requirements to the information systems supporting the keeping of the digital map and supplying the land information system. Therefore, preparation of a map required the acquisition of the following information about the objects: object code, object identification, the geometric shape of the object, the list of coordinates locating the object in the field, object attributes provided for by the Guideline, data source on the object location, the date of execution and last modification of the object, the KERG number of the documentation which the data about the object derives from.

The BDOT Regulation of 2013 [14] changed the existing approach to this kind of cartographic documentation. The current base map is therefore a report generated from several coexisting databases:

- BDOT500 - database of topographic objects with the detail that ensures the preparation of cartographic documentation in the scales of 1:500 - 1:5000, created by the processing of source materials existing in the resource and which are the content of the base map and other individual large-scale maps, as well as those captured from other public records,

- GESUT - surveying records of the network of public utilities, which is made up of the data captured from the entities who manage networks of utilities and from the previously existing large-scale maps, including the base map,

- PRG - database of the state register of boundaries and surface areas of the territorial division units of the country, 
- EGiB - database of the register of land and buildings (real estate cadastre),

- PRPOG - database of the national register of basic geodetic controls,

- BDSOG - database of detailed geodetic controls.

Out of the above-mentioned databases applicable across the whole territory of Poland, the following databases are established at the district level: BDOT500, GESUT, EGiB and BDSOG. The issues of building an integrated database and cartographic editing are discussed in $[3,9,10,21]$.

\section{Changes in the Base Map Editing with Respect to the Technical Guideline K-1 and the BDOT Regulation}

This chapter will compare the most important elements regarding the editing of the map in the light of the provisions of the Technical Guideline K-1 of 1998. (Appendix 1, Part B), the BDOT Regulation of 2013 (Appendix 7, Chapter 3) and the BDOT Regulation of 2015. In the BDOT Regulation of 2015, the descriptions relating to the objects are also objects of the database. Chapter 3 of Appendix 6 defines the label, or the legend, which is to appear inside or next to the object on the map. However, Chapter 3 of Appendix 7 of the BDOT Regulation of 2015 contains the principles of cartographic editing of the base map.

Based on these legal acts, Tables 1-6 summarize the relevant fragments of the analyzed laws, in terms of the subsequent factors taken into account during the conversion process of the database resources and editing of the map content.

To ensure the clarity of the comparisons, colors were used in accordance with the legend:

- green - recommendations which have remained unchanged in the Regulation in relation to the Technical Guideline K-1,

- red - recommendations which have changed,

- blue - new provisions introduced by the Regulation.

Table 1. Summary of the differences in editing of the map - overlapping of drawings

\begin{tabular}{||l|l|l||}
\hline \multicolumn{1}{|c|}{ Technical Guideline K-1 } & \multicolumn{1}{|c|}{ BDOT Regulation of 2013 } & $\begin{array}{c}\text { BDOT Regulation } \\
\text { of } 2015\end{array}$ \\
\hline \begin{tabular}{|l|l|} 
§ 6. The symbol obscures contours of the situation, with the exception of the \\
cartographic sign of a tree continuous line obscures dashed lines, thick line \\
obscures thin lines
\end{tabular} & $\begin{array}{l}\text { § 6. Lines going through the cartographic } \\
\text { sign of a tree remain visible }\end{array}$ & No change \\
\hline $\begin{array}{l}\text { A principle should be adopted that } \\
\text { descriptions are obscured by the } \\
\text { map drawing (with the exception } \\
\text { of the height of the contour line) }\end{array}$ & $\begin{array}{l}\text { § 6. Descriptions of the objects obscure the } \\
\text { map drawing }\end{array}$ & \\
\hline
\end{tabular}


Table 2. Summary of the differences in editing of the map - descriptions

\begin{tabular}{|l|l|l||}
\hline \multicolumn{1}{|c|}{ Technical Guideline K-1 } & BDOT Regulation of 2013 & $\begin{array}{l}\text { BDOT Regulation } \\
\text { of } 2015\end{array}$ \\
\hline $\begin{array}{l}\text { Elongated objects (roadways, rivers) } \\
\text { are denoted along the object, in italics, } \\
\text { according to the principle that the } \\
\text { denotations always run (the last letter } \\
\text { relative to the first one) in azimuths of } \\
\text { less than } 180 \text { degrees }\end{array}$ & $\begin{array}{l}\text { § 8. descriptions of elongated objects, } \\
\text { especially of roadways or flowing water, } \\
\text { are placed along these objects }\end{array}$ & No change \\
\hline $\begin{array}{l}\text { Description of surface objects is placed inside the described contour, and if there } \\
\text { is lack of space - a reference is used }\end{array}$ & No change \\
\hline $\begin{array}{l}\text { Description of the contour line } \\
\text { obscures the contour, the top of the } \\
\text { description indicates the direction of } \\
\text { the area height increase }\end{array}$ & $\begin{array}{l}\text { § 8. The entry abrogated (the new } \\
\text { provisions do not provide for the contour } \\
\text { line) }\end{array}$ & No change \\
\hline $\begin{array}{l}\text { Description of the objects: natural altitude point and artificial altitude point are } \\
\text { denoted parallel to the } Y \text { axis of the coordinate system, if such a position leads to } \\
\text { a loss of clarity, rotation is allowed }\end{array}$ & \begin{tabular}{l} 
No change \\
\hline \multicolumn{2}{|l|}{ altitude point for the object: roadway is } \\
placed parallel to its edge
\end{tabular} & No change \\
\hline $\begin{array}{l}\text { Meters from decimals in heights are } \\
\text { separated by a point }\end{array}$ & The entry abrogated & No change \\
\hline
\end{tabular}

Source: own studies based on $[8,14,15]$

Table 3. Summary of the differences in editing of the map outline and description of the building

\begin{tabular}{|c|c|c|}
\hline "Technical Guideline K-1 & BDOT Regulation of 2013 & BDOT Regulation of 2015 \\
\hline- & $\begin{array}{l}\text { §7. Objects of the GESUT } \\
\text { database are not presented in the } \\
\text { contours of the objects building }\end{array}$ & The entry abrogated \\
\hline $\begin{array}{l}\text { The text specifying the } \\
\text { predominant function of the } \\
\text { building and the number of } \\
\text { the highest story is placed } \\
\text { in one sequence, parallel to } \\
\text { the } y \text {-axis of the coordinate } \\
\text { system }\end{array}$ & $\begin{array}{l}\S 11 \text {. The whole description of the } \\
\text { object: building is placed in one } \\
\text { sequence, parallel to the y-axis of } \\
\text { the coordinate system, with the } \\
\text { exception of the serial number }\end{array}$ & No change \\
\hline $\begin{array}{l}\text { Address number should } \\
\text { be drawn on the building } \\
\text { parallel to the wall facing } \\
\text { the street, with the basis } \\
\text { towards the axis of the } \\
\text { street (in the case of housing } \\
\text { estates, when one plot is } \\
\text { developed with a number } \\
\text { of residential buildings with } \\
\text { different address numbers) }\end{array}$ & $\begin{array}{l}\text { § 10. Serial number is placed on } \\
\text { the building, parallel to the wall } \\
\text { of the building from the side of } \\
\text { the street, and according to the } \\
\text { north direction }\end{array}$ & $\begin{array}{l}\text { §9. Serial number is placed in } \\
\text { the contour of the building, with } \\
\text { the base parallel to the wall of the } \\
\text { building from the side of the street }\end{array}$ \\
\hline
\end{tabular}


Table 3. cont.

\begin{tabular}{|c|c|c|}
\hline Technical Guideline K-1 & BDOT Regulation of 2013 & BDOT Regulation of 2015 \\
\hline $\begin{array}{l}\text { The text specifying the } \\
\text { number of the top story } \\
\text { consists of an Arabic } \\
\text { numeral following the letter } \\
\text { defining the function of the } \\
\text { building, description of one } \\
\text { story is omitted, the attic is } \\
\text { not included in the number } \\
\text { of stories }\end{array}$ & $\begin{array}{l}\S 11 \text {. Description of the object: the } \\
\text { building consists of the following } \\
\text { elements: } \\
\text { 1) the number of the highest } \\
\text { story, denoted with an Arabic } \\
\text { numeral, if specified; } \\
\text { 2) the letter denoting the function } \\
\text { of the building, if specified; } \\
\text { 3) the serial number, if specified }\end{array}$ & $\begin{array}{l}\text { §9. Description of the object: the } \\
\text { building consists of the following } \\
\text { elements: } \\
\text { 1) the letter denoting the function } \\
\text { of the building, corresponding to its } \\
\text { PKOB class [17] } \\
\text { 2) the serial number, if specified } \\
\text { 3) denotation of the number of } \\
\text { over ground stories of the building, } \\
\text { described with an Arabic numeral, } \\
\text { if specified }\end{array}$ \\
\hline
\end{tabular}

Source: own studies based on $[8,14,15]$

Table 4. Summary of the differences in editing of the map names of roads and squares

\begin{tabular}{|c|c|c|}
\hline Technical Guideline K-1 & BDOT Regulation of 2013 & BDOT Regulation of 2015 \\
\hline \multicolumn{2}{|c|}{$\begin{array}{l}\text { §9. Street names are marked without the abbreviation } u l . \text {, but } \\
\text { abbreviations al. (Avenue) and } p l \text {. (Square) are used }\end{array}$} & $\begin{array}{l}\text { § 7. Descriptions of the } \\
\text { objects: street, alley, sidewalk, } \\
\text { walkway or path consist of the } \\
\text { abbreviations "j.", "al.", "ch.", } \\
\text { "pas." or "sc", and description } \\
\text { of the type of surface, if } \\
\text { specified }\end{array}$ \\
\hline \multirow{2}{*}{$\begin{array}{l}\text { Roads and public squares are } \\
\text { the optional contents of the base } \\
\text { map. The roads located within } \\
\text { parcels are not the contents of the } \\
\text { map, with the exception of the } \\
\text { roads running in large areas with } \\
\text { uniform ownership [...], and which } \\
\text { are permanent roads of internal } \\
\text { transport or those connecting } \\
\text { places of residence. When the road } \\
\text { on the map drawing is not clearly } \\
\text { emphasized [...], it should be } \\
\text { denoted with the abbreviation } d r\end{array}$} & $\begin{array}{l}\text { §9. Roadways without the } \\
\text { name of the street are denoted } \\
\text { with the abbreviation } d r\end{array}$ & $\begin{array}{l}\S 7 \text {. Description of the object: } \\
\text { street representing the value } \\
\text { of the attribute name is placed } \\
\text { parallel to its axis }\end{array}$ \\
\hline & $\begin{array}{l}\text { §9. The name of a roadway or } \\
\text { a square consists of the name } \\
\text { of a street or a square and } \\
\text { specification of the type of its } \\
\text { surface. It is allowed to use an } \\
\text { abbreviated name, according } \\
\text { to the attribute: } \\
\text { NazwaGlownaCzesc from } \\
\text { BDOT500 }\end{array}$ & $\begin{array}{l}\S 7 \text {. Description of the object is } \\
\text { placed parallel to the } y \text {-axis of } \\
\text { the coordinate system in the } \\
\text { case of the name of a square }\end{array}$ \\
\hline \multicolumn{2}{|c|}{$\begin{array}{l}\text { - Surface structures having their own names are denoted with } \\
\text { abbreviations contained in the list of abbreviations and denotations; } \\
\text { if no abbreviation was provided for, full names are used }\end{array}$} & The entry abrogated \\
\hline $\begin{array}{l}\text { Areas of the National Railways } \\
\text { and National Forests are described } \\
\text { depending on the available space, } \\
\text { with an abbreviation or with a full } \\
\text { name, but without the use of the } \\
\text { word area. The objects Additional } \\
\text { Text are used for this purpose }\end{array}$ & The entry abrogated & No change \\
\hline
\end{tabular}


Table 5. Summary of the differences in editing of the map names and numbers of surface objects

\begin{tabular}{||l|l|l||}
\hline \multicolumn{1}{|c||}{ Technical Guideline K-1 } & \multicolumn{1}{|c||}{ BDOT Regulation of 2013 } & BDOT Regulation of 2015 \\
\hline \hline $\begin{array}{l}\text { Any texts of the names and } \\
\text { area numbers [...], with the } \\
\text { exception of the address } \\
\text { number, should be marked } \\
\text { parallel to the } Y \text { axis of the } \\
\text { coordinate system. The } \\
\begin{array}{l}\text { address number should be } \\
\text { make on the plot parallel to } \\
\text { the axis of the street }\end{array}\end{array}$ & $\begin{array}{l}\text { llowing water, are placed parallel to their } \\
\text { floundaries - the names and numbers of } \\
\text { surface objects: cadastral units, cadastral } \\
\text { districts cadastral plots, land uses, } \\
\text { are placed parallel to the y-axis of the } \\
\text { coordinate system }\end{array}$ & No change \\
\hline $\begin{array}{l}\text { If such positions of parcel numbers result in the loss of clarity, and no } \\
\text { reference can be used, their rotation is allowed }\end{array}$ & The entry abrogated \\
\hline
\end{tabular}

Source: own studies based on $[8,14,15]$

Table 6. Summary of the differences in editing of the map - boundaries

\begin{tabular}{||l|l|l||}
\hline \multicolumn{1}{|c||}{ Technical Guideline K-1 } & \multicolumn{1}{|c||}{$\begin{array}{c}\text { BDOT Regulation of } \\
\text { 2013 }\end{array}$} & $\begin{array}{c}\text { BDOT Regulation of } \\
2015\end{array}$ \\
\hline \hline $\begin{array}{l}\text { § 12. If boundaries of territorial units and cadastral units overlap, then the } \\
\text { base map depicts only the boundaries of the higher order }\end{array}$ & No change \\
\hline $\begin{array}{l}\text { If a boundary, other than a plot boundary, runs } \\
\text { in the middle of the contour [...] which is wide } \\
\text { enough to fit inside a symbol of a boundary - this } \\
\text { symbol should be used; when the contour is too } \\
\text { narrow, or the boundary runs along boundaries of } \\
\text { land plots - secondary symbol should be used }\end{array}$ & The entry abrogated & No change \\
\hline
\end{tabular}

Source: own studies based on $[8,14,15]$

\section{Changes in the Base Map Editing with Respect to the Description of the Function of Buildings}

One of the basic, yet obligatory contents of the base map, are buildings and structures. In addition to their graphical representation, the information which was obligatory for a building included in the base map, according to the Technical Guideline K-1, was the predominant function of the building and the number of stories. Due to the volume of the study, only the changes in the denotation of the function of the building, defined by a letter abbreviation, will be presented $[2,4]$. The amendment to the Regulation on the register of land and buildings of 2013 introduced the obligation to specify the class, type and function of buildings. Thus, in the Regulation on BDOT500 and the base map, there were a lot more descriptions used in defining the so-called functions of buildings. 
It should be emphasized that, despite the verbal description in the Regulation: the function of the building, it is actually supposed to be the determination of its class according to the Polish Classification of Types of Constructions [17].

Table 7. Comparison of functions of buildings and classes of buildings

\begin{tabular}{|l|c|l||}
\hline \multicolumn{1}{|c|}{ Technical Guideline K-1 - function } & $\begin{array}{c}\text { Function } \\
\text { (Class) }\end{array}$ & \multicolumn{1}{|c||}{ BDOT Regulation - PKOB Class } \\
\hline residential building & $\mathrm{m}$ & does not exist \\
\hline does not exist & $\mathrm{mj}$ & single-family residential building \\
\hline does not exist & $\mathrm{md}$ & residential building with two apartments \\
\hline does not exist & $\mathrm{mt}$ & $\begin{array}{l}\text { residential building with three or more } \\
\text { apartments }\end{array}$ \\
\hline does not exist & $\mathrm{t}$ & communal residential building \\
\hline transport or communication building & $\mathrm{g}$ & farm building \\
\hline service building & $\mathrm{u}$ & commercial building \\
\hline does not exist & $\mathrm{h}$ & hotel building \\
\hline commercial building & $\mathrm{z}$ & reservoir, silo and storage building \\
\hline warehouse or storage building & $\mathrm{k}$ & muspital and medical care building \\
\hline healthcare, social care building & $\mathrm{i}$ & $\begin{array}{l}\text { other non-residential building, not classified } \\
\text { elsewhere }\end{array}$ \\
\hline building for cultural, educational, \\
religious purposes
\end{tabular}

Source: own studies based on $[8,14,15]$

Table 7 illustrates the comparison of changes in letter denominations of the function of the building and an explanation of the meaning of each letter symbol. 
Based on the comparison contained in Table 7, significant discrepancies can be seen in the description of the functions of buildings according to K-1 and the BDOT Regulation, including:

- only two letter abbreviations of the functions are identical in their description and meaning in these two acts of law - this applies to office buildings $\boldsymbol{b}$ and industrial buildings $p$;

- provisions of the BDOT Regulation divide residential buildings into: single-family residential buildings $m j$, residential buildings with two apartments $m d$, residential buildings with three or more apartments $m t$ and communal residential buildings $m z$; the abrogated Technical Guideline K-1 provided for only one denotation of buildings with residential function $m$;

- commercial buildings were previously denoted with the letter $\boldsymbol{h}$, and are currently marked with the letter $\boldsymbol{u}$; thus, the same object will have different denotations on the map, depending on when (and according to what standards) the map was created;

- a similar situation applies to university buildings. According to the Technical Guideline K-1, they were denoted with the letter $k$, because they belonged to the group including buildings used for cultural, educational and religious purposes; currently, in accordance with the Regulation, they form a separate group which includes school buildings and research institutions, and are marked with the letter $\boldsymbol{e}$;

- the situation with the buildings denoted with the letter $h$ is quite the opposite; although the letter denotation is the same in the Technical Guideline K-1 and in the BDOT Regulation, these acronyms have different meaning; the Technical Guideline K-1 describes the letter $\boldsymbol{h}$ as representing the commercial building, while the BDOT Regulation translates $h$ as the hotel building.

In conclusion, it should be emphasized that the content of the base map must be read with the knowledge of when and according to which provisions a given map was prepared. Possible variations of the descriptions of buildings appearing on the map, which can only result from the revised legislation, should be taken into account. An example of a fragment of the same area, presented according to the various provisions of law, was presented in Figure 1.

It should be added, that the update of the map kept according to the previous standards should be consistently continued in the same standard. Only after the conversion of the map content to new regulations, its form changes and may be updated according to the latest regulation [13]. It should be emphasized that the use of the base map is of fundamental importance to surveying works such as planning works, preparation of maps for design purposes, establishing rights-of-way, or even the construction of the 3D cadastral system $[5,7,12,18]$. Therefore, inconsistency in the content of the map resulting from changes in the legislation is not beneficial to the user. 

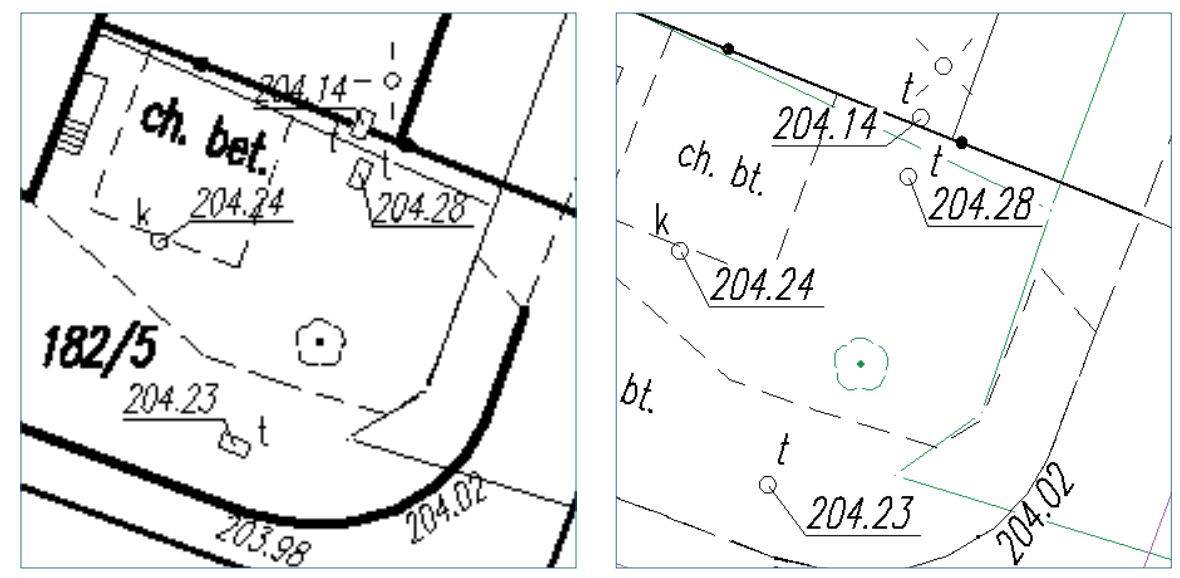

Fig. 1. Hatches for manholes, streetlights, trees, curbs and descriptions according to the Technical Guideline K-1 and the BDOT Regulation

\section{Summary}

As it follows from the above comparisons, the new Regulation on the preparation of the base map significantly modifies the manner of its creation, both in graphic and editing terms. The changes also apply to text attributes, abbreviations and displayed names. The manner of the coding of each item has changed as well. Only 31 objects found in the Technical Guideline K-1 remained unchanged in the BDOT Regulation of 2013; however, 89 new objects were introduced. The remaining objects were modified, both in terms of classification (e.g. an element was a point or a linear object, and currently it is a surface object), name, or symbol visualization.

At the moment, the most difficult task for IT systems is the requirement of the conversion of the map content into the GML format, compatible with the application scheme. Although the new legal act provides this scheme, numerous differences in the coding of objects, and the resulting reservations as to the possibility of using the scheme appearing in the surveying environment, allows for the conclusion that currently the transfer of all the information from the base map to the GML format is difficult to carry out.

Despite the controversial issues in the applicable laws which have been emerging, companies managing geodetic and cartographic data take steps to adapt their applications to the new requirements, especially with respect to the appropriate surveying software. An attempt to convert the data, however, is a very complex task and it cannot be done in a fully automated manner without any losses. The phenomenon of frequent amendments to the provisions of law, occurring in recent years in Poland, results in a lack of consistency in the semantic content of the base map, prepared based on the previous wording of the provisions in the legislation. 


\section{References}

[1] Balawejder M., Buśko M., Cellmer R., Juchniewicz-Piotrowska K., Leń P., Mika M., Szczepankowska K., Wójciak E., Wójcik-Leń J., Źróbek S.: Aktualne problemy gospodarki nieruchomościami w Polsce na tle przemian organizacyjno-prawnych [The current problems of real estate management in Poland against the background of organizational and legal changes]. Wyższa Szkoła Inżynieryjno-Ekonomiczna, Rzeszów 2015.

[2] Buśko M.: Analiza wpływu zmian przepisów prawa dotyczacych budynków $w$ aspekcie aktualizacji bazy danych katastru nieruchomości [Analysis of the influence of amendments to the legal provisions relating to building structures on keeping the real estate cadastral database updated]. Infrastruktura i Ekologia Terenów Wiejskich, $\mathrm{nr}$ II/1, 2016, pp. 395-410.

[3] Buśko M.: Integrated database as the basis for the modern real estate cadastre. Infrastruktura i Ekologia Terenów Wiejskich, nr IV/4, 2016, pp. 1833-1845.

[4] Buśko M.: Problematyka ujawniania funkcji użytkowej budynku w operacie ewidencyjnym w aspekcie obowiazujacych przepisów prawnych [Issues concerning disclosing useful functions of a building in cadastral documentation with respect to binding legal regulations]. Przegląd Geodezyjny, r. 86, nr 6, 2014, pp. 3-8.

[5] Buśko M., Przewięźlikowska A.: Analiza przepisów prawnych dotyczacych treści map do celów projektowych w aspekcie uzgodnionych sieci uzbrojenia terenu [Analysis of legal regulations concerning the content of maps for design purposes with respect to approved networks of facilities]. Przegląd Geodezyjny, r. 82, nr 10, 2010, pp. 7-10.

[6] Buśko M., Przewięźlikowska A.: Metodyka opracowania numerycznej mapy zasadniczej na przykładzie wybranego obiektu [Methods of preparation of the digital basic map on the example of a selected object]. Geomatyka i Inżynieria: kwartalnik naukowy Państwowej Wyższej Szkoły Techniczno-Ekonomicznej w Jarosławiu, nr 1, 2012, pp. 5-24.

[7] Butryn K., Preweda E.: Selected Issues of Establishing and Functioning of the Transmission Easement. Geomatics and Environmental Engineering, vol. 10, no. 1, 2016, pp. 33-44.

[8] Instrukcja Techniczna K-1: Mapa zasadnicza [Technical Guideline K-1: The Base Map]. Główny Geodeta Kraju, Warszawa 1998.

[9] Jiang X., Bi J., Nan G. et al.: A Survey on Information-Centric Networking: Rationales, Designs and Debates. China Communications, vol. 12, issue 7, 2015, pp. 1-12.

[10] Lupa M., Kozioł K., Leśniak A.: An attempt to automate the simplification of building objects in multiresolution databases. [in:] Beyond Databases, Architectures and Structures: 11th International Conference, BDAS: Ustron, Poland, May 26-29, 2015, Springer International Publishing, 2015, pp. 448-459.

[11] Mika M.: Model systemu katastralnego w jezyku analizy obiektowej OOA. Geomatics and Environmental Engineering, vol. 1, no. 4, 2007, pp. 201-211. 
[12] Mika M.: Thematic Map as a Basis for the World's Geoinformation System in Chronological Approach. Geomatics and Environmental Engineering, vol. 8, no. 1, 2014, pp. 53-60.

[13] Mika M., Przewięźlikowska A., Siejka M.: Monitoring rynku programów geodezyjnych wykorzystywanych do opracowania mapy sytuacyjno-wysokościowej na terenie powiatu krakowskiego. Czasopismo Inżynierii Lądowej, Środowiska i Architektury, z. 62, nr 3/II, 2015, pp. 301-313.

[14] Rozporzadzenie Ministra Administracji i Cyfryzacji z dnia 12 lutego 2013 r. w sprawie bazy danych geodezyjnej ewidencji sieci uzbrojenia terenu, bazy danych obiektów topograficznych oraz mapy zasadniczej. Dz.U. 2013, poz. 383 [Regulation of the Minister of Administration and Digitization of 12 February 2013 on the database of surveying records of public utilities, databases of topographic objects and the base map. Official Journal of 2013, item 383].

[15] Rozporzadzenie Ministra Administracji i Cyfryzacji z dnia 2 listopada 2015 r. $w$ sprawie bazy danych obiektów topograficznych oraz mapy zasadniczej. Dz.U. 2015, poz. 2028 [Regulation of the Minister of Administration and Digitization of 2 November 2015 on the database of topographic objects and the base map. Official Journal of 2015, item 2028].

[16] Rozporzadzenie Ministra Spraw Wewnętrznych i Administracji z dnia 24 marca 1999 r. w sprawie standardów technicznych dotyczacych geodezji, kartografii oraz krajowego systemu informacji o terenie. Dz.U. 1999, nr 30, poz. 297 [Regulation of the Minister of Internal Affairs and Administration of 24 March 1999 on technical standards for geodesy, cartography and the national land information system. Official Journal of 1999, No. 30, item 297].

[17] Rozporzadzenie Rady Ministrów z dnia 30 grudnia 1999 r. w sprawie Polskiej Klasyfikacji Obiektów Budowlanych (PKOB). Dz.U. 1999, nr 112, poz. 1316 [Regulation of the Council of Ministers of 30 December 1999 on the Polish Classification of Types of Constructions. Official Journal of 1999, No. 112, item 1316].

[18] Siejka M., Ślusarski M., Zygmunt M.: 3D+time Cadastre, possibility of implementation in Poland. Survey Review, vol. 46, issue 335, 2014, pp. 79-89.

[19] Ustawa $z$ dnia 4 marca 2010 r. o infrastrukturze informacji przestrzennej. Dz.U. 2010, nr 76, poz. 489 [The Act of 4 March 2010 on Infrastructure for Spatial Information. Official Journal of 2010, No. 76, item 489].

[20] Ustawa z dnia 5 czerwca 2014 r. o zmianie ustawy - Prawo geodezyjne $i$ kartograficzne oraz ustawy o postępowaniu egzekucyjnym w administracji. Dz.U. 2014, poz. 897 [The Act of 5 June 2014 amending the Act - Geodetic and Cartographic Law and the Law on enforcement proceedings in administration. Official Journal of 2014 item 897].

[21] Vondrakova A., Vozenilek V.: Concept of a Formalized Record of GIS Data Visualization for Map Creation. [in:] 15 th International Multidisciplinary Scientific GeoConference SGEM 2015, Conference Proceedings, June 18-24, 2015, Book 2, Vol. 2, pp. 765-770. 